\title{
Imaging of giant cell tumor and giant cell reparative granuloma of bone
}

\author{
Dr. Hiral Hapani M.D. Radiology ${ }^{1}$, Dr. Jagruti Kalola M.D. Radiology ${ }^{2}$, Dr. Jay \\ Hapani D.N.B. Radiology ${ }^{3}$, Dr. Gauravi Dhruva M.D. Pathology ${ }^{4}$

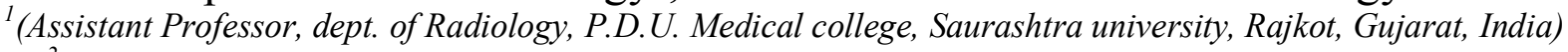 \\ ${ }^{2}$ (Associate Professor, dept. of Radiology, P.D.U. Medical college, Saurashtra university, Rajkot, Gujarat, \\ India) \\ ${ }^{3}$ (Consultant Radiologist, Milestone Hospital, Rajkot, Gujarat, India) \\ ${ }_{4}^{4}$ (Professor and Head of Dept. Pathology, P.D.U. Medical college, Saurashtra university, Rajkot, Gujarat, \\ India)
}

\begin{abstract}
:
Aims:

- Discuss imaging features of giant cell tumor of bone and giant cell reparative granuloma

- Discuss the role of different imaging modalities in diagnosis of giant cell tumor and giant cell reparative granuloma.

- Explain the pathologic basis for radiologic features of giant cell tumor and giant cell reparative granuloma

- Discuss types of malignant giant cell tumors with their imaging features.

- Describe the traditional treatment of giant cell tumors and list the common post operative complications
\end{abstract}

Materials and Methods: This retrospective study of 10 patients was conducted in Shri M.P.SHAH Medical college and GURU GOBIND Singh hospital, Jamnagar.

Observations: The most common site for giant cell tumor in our observation was femur; some rare locations for giant cell tumor observed were flat bones like frontal bone and acromion; the single case of malignant giant cell tumor involved the patella. On plain radiography, majority of cases of giant cell tumor showed a well defined, eccentric, lytic lesion with non sclerotic border involving the epi-metaphyseal region of long bones with sub articular extension in patients with closed physis. On MRI, majority of patients showed well defined lesions which appeared hypointense on TIWI and heterogeneous predominantly hyperintense on T2W and STIRWI. The heterogeneous signal on T2WI reflected the inherent tissue inhomogenity. The single case of malignant giant cell tumor in our study, involved the patella in a middle aged female. It presented as expansile lytic lesion involving the patella with destruction of the cortical outline and soft tissue mass replacing majority of the bone. It showed intense enhancement with areas of central necrosis on post contrast scans. It also caused destruction of the anterior tibial cortex with minimal extension into tibial matrix. There was post operative recurrence in one patient who was treated with curettage and cement placement. The single case of giant cell reparative granuloma showed a well defined multiloculated expansile lytic lesion in right temporal bone. On MRI, it appeared hypointense on T1WI and heterogeneous on T2WI and showed homogenous moderate post contrast enhancement

Conclusion: Giant cell tumor of bone is typically benign lesion but may demonstrate aggressive imaging features or fluid fluid levels. Traditional treatment of giant cell tumor is associated with high recurrence rate. Giant cell reparative granuloma is a reparative process rather than a true neoplasm. It presents with imaging findings quite similar to giant cell tumor. However, it commonly affects the mandible, maxilla, small bones of hand and feet.

Key Words: Giant cell tumor, giant cell reparative granuloma, histopathological correlation, imaging, treatment

Abbreviations used: GCT-giant cell tumor, GCRG-giant cell reparative granuloma

\section{Introduction:}

GCT was first described by Cooper and Travers in 1818. [1] GCT is a relatively common bone tumor accounting for 4 to 9.5 percent of all primary bone tumors and 18-23 percent of all benign bone tumors. [27]Radiographically, it classically appears as a well defined eccentric lytic lesion with narrow zone of transition but lacking sclerotic border and centered in the meta-epiphysis of long bones with extension into sub articular region. It may be associated with expansile remodeling of bone but classically lacks internal mineralization.GCT is classically benign and solitary. However, multiple lesions have been described (rarely, associated with Paget's disease) and 5-10\% lesions are malignant. [2-7] 
GCRG of bone is actually a reparative process rather than a true neoplasm. It commonly affects the mandible and maxilla. Second most common site is the short bones of hands and feet. Radiographically, it appears as a well defined expansile lytic lesion centered in the metadiaphysis with sparing of sub articular region. It may show matrix mineralization in contrast to classic GCT.

Histologically, there is prominent and diffuse presence of multinucleated giant cells in a background of mononuclear cells; the nuclei of both the above mentioned cells are indistinguishable - a finding that differentiates GCT from many other pathologies. [8-9]A true GCT should contain a large number of giant cells in a diffuse distribution in a background of mononuclear cells.

\section{Materials and Methods:}

This retrospective study was conducted in the department of Radio-diagnosis, Shri M.P. Shah medical college and Guru Gobind Singh Hospital, Jamnagar. The patients were first subjected to plain radiography, following which CT scan and MRI were conducted

\subsection{Methodology:}

Xray: 300 and 500 m.A. Philips M.R.S.

CT scan: G.E. 16 slice CT scanner

MRI: Siemens' Magnatom Essenza $1.5 \mathrm{~T}$

\section{2 .Inclusion Criteria:}

- Patients presenting with bony complaints.

- Pain/restriction of joint movement due to obvious swelling

- Xray favoring bone tumor

- Pathologic fracture.

\subsection{Exclusion Criteria:}

- Obvious history of trauma

- Patient in whom radiation/ MRI is contraindicated.

\section{Results}

A total 10 cases of GCT were studied and the following observations were made.

A total of 10 patients of GCT were studied. There was one patient of giant cell reparative granuloma. Out of all patients of GCT - 8 were males and 3 were females; majority of patients were in their 3rd and 4th decades. The oldest patient was 76 years old and the youngest patient was 20 years old. The most common site for GCT in our observation was femur; some rare locations for GCT observed in this study included flat bones like frontal bone and acromion; the single case of malignant GCT in our study involved the patella. The single case of GCRG involved the temporal bone in a 33 year old male patient. On plain radiography, majority of cases of GCT in our study showed a well defined, eccentric, lytic lesion with non sclerotic border involving the epimetaphyseal region of long bones with sub articular extension in patients with closed physis. Cortical breech was noted in 3 patients on Xray 6 patients on CT scan. Associated soft tissue mass was noted in 5 patients. Pathologic fracture was noted in one patient. On MRI, majority of patients showed well defined lesions which appeared hypointense on T1WI and heterogeneous predominantly hyperintense on T2W and STIRWI.The heterogeneous signal on T2WI reflected the inherent tissue inhomogenity. The single case of malignant GCT in our study, involved the patella in a middle aged female. It presented as expansile lytic lesion involving the patella with destruction of the cortical outline and soft tissue mass replacing majority of the bone. It showed intense enhancement with areas of central necrosis on post contrast scans. It also causes destruction of the anterior tibial cortex with minimal extension into tibial matrix. There was post operative recurrence in one patient who was treated with curettage and cement placement.

GCRG - The single case of GCRG showed a well defined multi loculated expansile lytic lesion in right temporal bone. On MRI, it appeared hypointense on T1WI and heterogeneous on T2WI.

\subsection{Epidemiology:}

\section{Discussion:}

GCT is a relatively common skeletal tumor. Although, it occurs in all races; there is unusually high prevalence in China and Southern India (State of Andhra Pradesh) [10-12]. Benign GCT affects females more commonly than males with a ratio of $1.1: 1$ to $1.5: 1 .[6,8,11,19-21]$.Malignant GCTs are more common in males with a ratio of 3:1[5-7].The vast majority of lesions occur in skeletally mature patients in the age group of $20-50$ years.[2-7,13].Peak prevalence is in the third decade. 


\subsection{Lesion location:}

Approximately 80 to 99 percent of lesions extend to within $1 \mathrm{~cm}$ of sub chondral bone. $[3,7,14,15]$ The lesions arise from the metaphyseal side of the epiphyseal plate.[16,17,13,18,19]The most common location of GCT is around the knee joint $50-65 \%$ )[23,2-7,19-22].Common locations in descending order are distal femur, proximal tibia, distal radius, sacrum, proximal humerus.[2-7,25,20-23,26-29]GCT can also occur in patella ,the largest sesamoid bone. Upto $15 \%$ of GCT occurs in flat bones like pelvis, sacrum, spine and calvaria. Less than $1 \%$ GCT occurs in scapula [30]

\subsection{Imaging:}

Lesions invariably demonstrate geographic bone lysis, most commonly associated with narrow zone of transition and lacking surrounding sclerosis. Although, majority of lesions are eccentrically located, lesions that are large at presentation may be located centrally. [14,15,31]GCT may also have aggressive features such as a wide zone of transition, cortical thinning, expansile remodeling or even cortical bone destruction with or without associated soft tissue mass. [32]Pathologic fracture, which may be complete or incomplete, is seen in $11 \%-37 \%$ of patients $[17,20,31]$. At radiography, GCTs often demonstrate prominent trabeculation (33\%-57\% of cases) with a resultant multi loculated appearance (soap bubble appearance) $[17,13,14,18,31]$

\subsection{Comparison of imaging modalities:}

Plain radiograph remains the mainstay of primary diagnosis. However, CT scan and MR imaging allow superior delineation and staging of GCTs.[33,34]CT improves detection of cortical thinning, pathologic fracture, periosteal reaction, and degree of osseous expansile remodeling compared with radiography [14,31]. CT also helps to confirm the absence of mineralization in GCT, although callus formation related to healing pathologic fracture may be seen. The solid portions of GCT demonstrate attenuation similar to that of muscle.

MR imaging is superior to CT in delineating soft-tissue tumor extent because of its improved contrast resolution. Conversely, $\mathrm{CT}$ is superior to MR imaging in evaluating periosteal reaction, pathologic fracture, and the absence of matrix mineralization.

MR imaging of GCT frequently reveals a relatively well-defined lesion with a low-signal-intensity margin representing either osseous sclerosis or a pseudo capsule .However, more invasive and aggressive growth may also be seen .The solid components of GCT demonstrate low to intermediate signal intensity at T1and T2-weighted MR imaging in the vast majority of cases.[35]This feature can be useful in excluding other subarticular lesions such as large solitary subchondral cyst, intraosseous ganglion, Brodie abscess, and clear cell chondrosarcoma that demonstrate high signal intensity at T2-weighted MR imaging. The cause of this appearance has been reported as hemosiderin deposition, although we believe it is more likely related to increased cellularity or high collagen content $[35,36,37]$

$\mathrm{ABC}$ components in GCT are relatively common (14\% of lesions) [2-7,34,35,38-44]. In addition, GCT is the most common lesion associated with secondary $\mathrm{ABC}$. The $\mathrm{ABC}$ regions frequently exhibit fluid levels at both modalities. These $\mathrm{ABC}$ areas demonstrate low attenuation at $\mathrm{CT}$, low or high signal intensity at $\mathrm{T} 1$ weighted MR imaging, and markedly increased signal intensity at T2-weighted MR imaging.[38-44]At advanced imaging, the solid components of GCT are easily distinguishable from the $\mathrm{ABC}$ areas. Recognition of and distinction between the cystic (ABC) and solid areas of a GCT can be vital for patient treatment for two important reasons: first, to prevent misdiagnosis of the lesion as a primary $\mathrm{ABC}$, which should contain only cystic components; and second, to allow biopsy to be directed at the solid portions of the lesions, which harbor diagnostic tissue, as opposed to $\mathrm{ABC}$ regions, which yield nonspecific blood. Contrast-enhanced $\mathrm{CT}$ or MR imaging can also help distinguish cystic from solid regions. Cystic areas enhance with a thin and delicate peripheral and septal pattern. In contrast, the solid regions of a GCT enhance diffusely, reflecting the hypervascular tissue seen at pathologic analysis.

\subsection{Malignant GCT:}

Malignant giant cell tumor is a term used to describe a heterogeneous group of giant cell-containing lesions that are capable of malignant behavior and of producing pulmonary metastases $[45,46]$. Benign metastasizing GCT is a form of malignant GCT in which the metastases demonstrate a histologically benign appearance identical to that of conventional GCT [7].These pulmonary mets may either remain stable or regress spontaneously. The term malignant GCT most frequently refers to a tumor in which there is de novo malignant transformation of a formerly benign GCT. It can either be primary or secondary. A secondary malignant GCT of bone is defined as "a sarcomatous growth that occurs at the site of a previously documented GCT, usually after previous radiation therapy and less commonly after a long latency period or repeated resections". The final type of malignant GCT is osteoclastic (giant cell) sarcoma. Pathologically, this lesion is defined as "a highly malignant tumor composed of anaplastic stromal and anaplastic osteoclast-like giant cells in which there is no evidence of tumor osteoid, bone or cartilage,"[7] 
The radiologic appearance of malignant GCT invariably includes cortical permeation and an associated soft-tissue mass, findings that reflect its aggressive behavior [46]

\subsection{Histo-pathological Appearance:}

Histologically, there is prominent and diffuse presence of multinucleated giant cells in a background of mononuclear cells; the nuclei of both the above mentioned cells are indistinguishable - a finding that differentiates GCT from many other pathologies.[8,9]A true GCT should contain a large number of giant cells in a diffuse distribution in a background of mononuclear cells.

\subsection{Treatment:}

Definitive treatment consists of intralesional surgical resection. Historically, curettage and bone grafting has been the treatment of choice for GCT, although marginal resection is associated with a high recurrence rate of $40 \%-60 \%$ [2-7,24]Wide resection shows a reduced recurrence rate $(7 \%)$ [47-54]however, this treatment often causes significant compromise of limb function, which may be difficult to justify in treatment of a benign lesion. Newer surgical treatments emphasize methods of extending surgical margins without use of wide resection to maintain limb function and limit recurrence[45,46].Curettage and filling the void with polymethylmethacrylate(PMMA) is associated with a $25 \%$ recurrence rate[48].Curettage with high-speed burring of the cavity combined with a thermal or chemical adjunct to extend the surgical margin has resulted in improved local control [48-51]For large and highly destructive GCTs, either primary or recurrent, wide resection and reconstruction with allograft or metal prostheses is often used. Because of the risk of secondary sarcomatous transformation, radiation therapy is generally reserved for tumors that are deemed inoperable.

\subsection{Imaging in Post treatment recurrence}

Radiologic evaluation of recurrence typically reveals new areas of bone destruction at the previous resection margin or resorption of intralesional bone graft material [48,55-60]. On MRI, the recurrent lesion follows the signal intensity of the primary lesion.

\subsection{Giant cell reparative granuloma}

GCRG is a reactive inflammatory process secondary to trauma and intraosseous hemorrhage and predominantly affects children and young women. [61,62]It arises from the periosteal connective tissue, whereas GCT originates in the connective tissue of the bone marrow.[62]

Radiologic appearances of GCT and GCRG are indistinguishable. Histologically, abundant multinucleated giant cells are evenly distributed in GCT [61,64] whereas they are unevenly distributed and contain fewer nuclei in GCRG. [63,65].

GCRG occurs in many bones, with the mandible, maxilla, and the small bones of the hand and feet being the most common sites. Extragnathic GCRG has another peak of occurrence in the 50- to 80-year range, with the most common site in the craniofacial region being the temporal bone. [61,65].

\section{Case 1: Classic GCT}

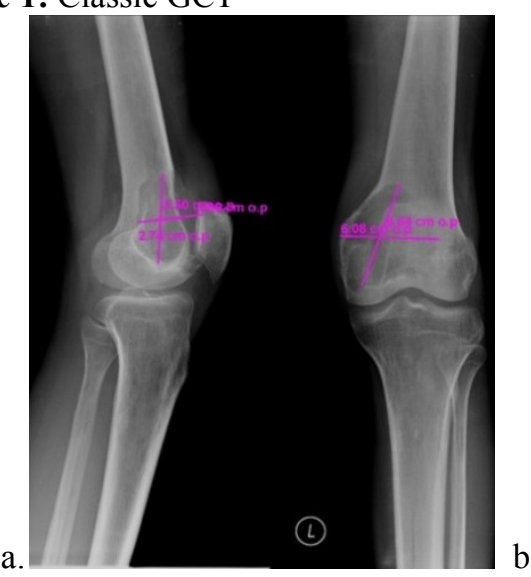

\section{Illustrations:}

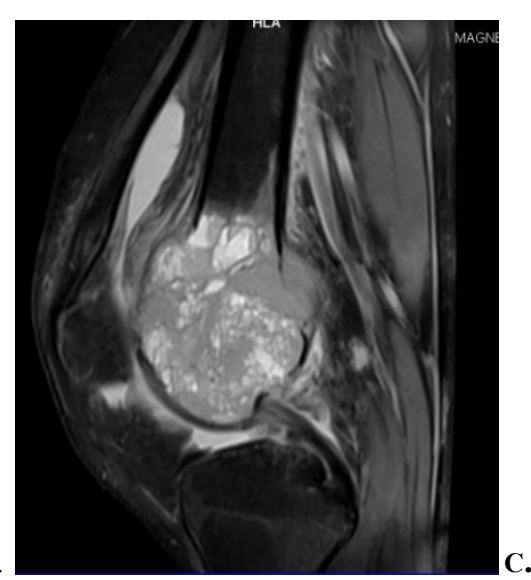

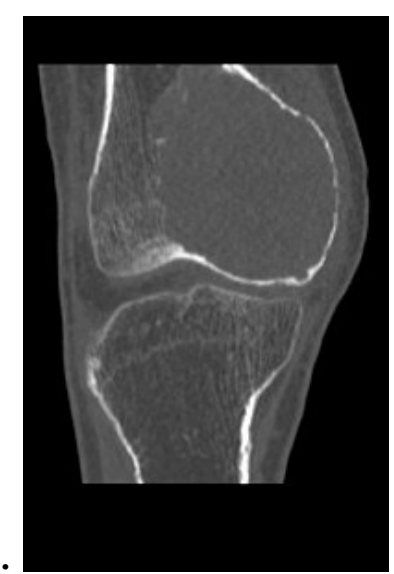



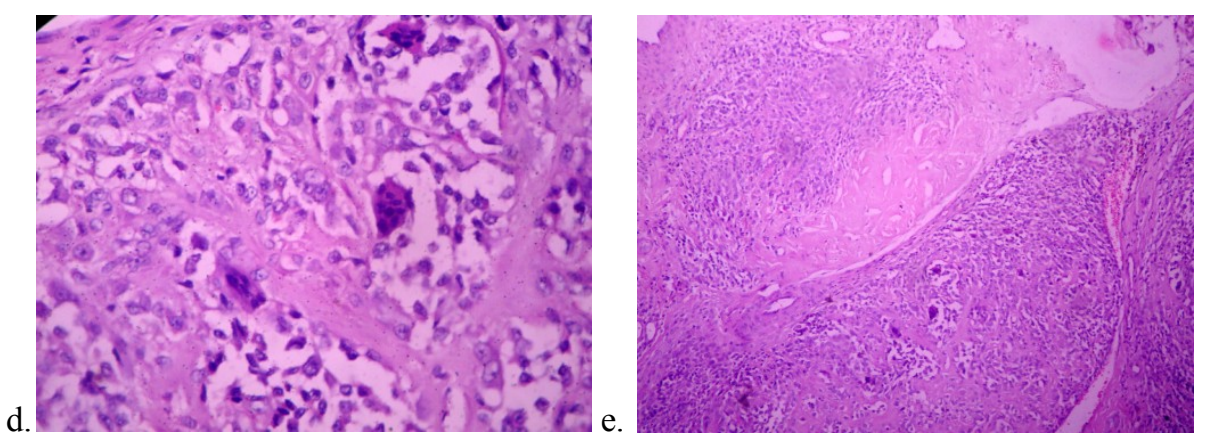

a, $\mathrm{c}$ : Well defined eccentric lytic lesion with non sclerotic margin involving the subarticular region of femur b: MRI - PDFS image -well defined cystic solid lesion in subarticular location of femur. The solid components appear hypointense on PDFS d,e: Even distribution of multinucleated giant cells in a background of mononuclear cells.

Case 2: Acromion GCT

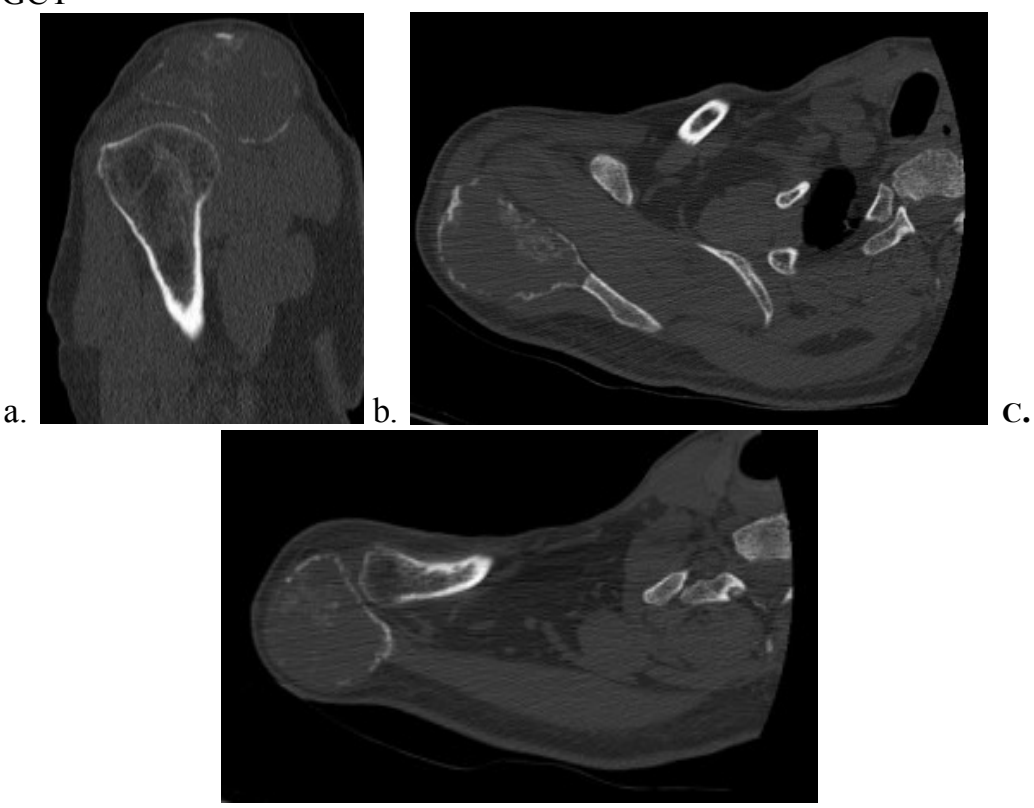

a,b.c: Sagittal, axial and coronal reformatt plain CT images reveal well defined lytic lesion in subarticular location of acromion process of right scapula causing expansile remodeling and cortical erosion.

Case 3: Recurrent GCT

a.

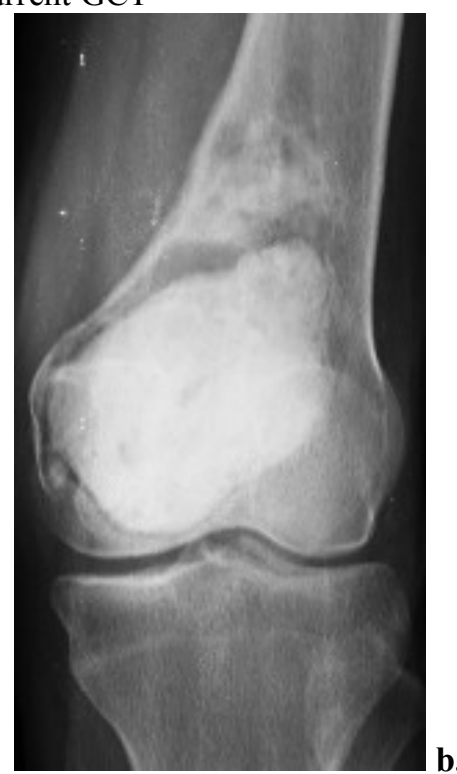

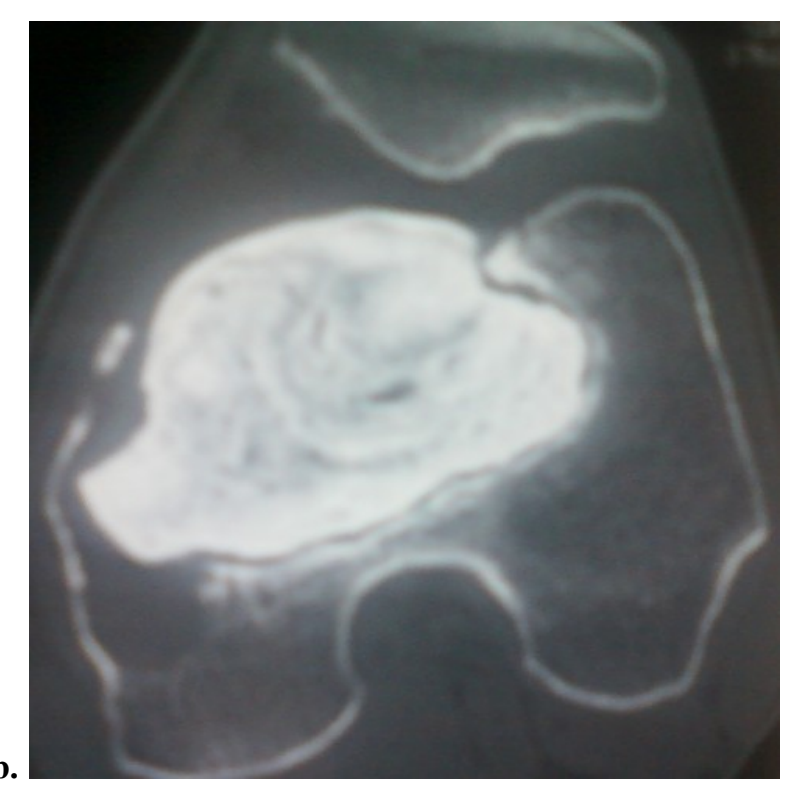

www.iosrjournals.org 
a: Development of a new area of radiolucency at the cement bone interface with pathological fracture b: Axial plain CT scan images revealing cortical erosion and pathological fracture

Case 4: Malignant GCT Patella
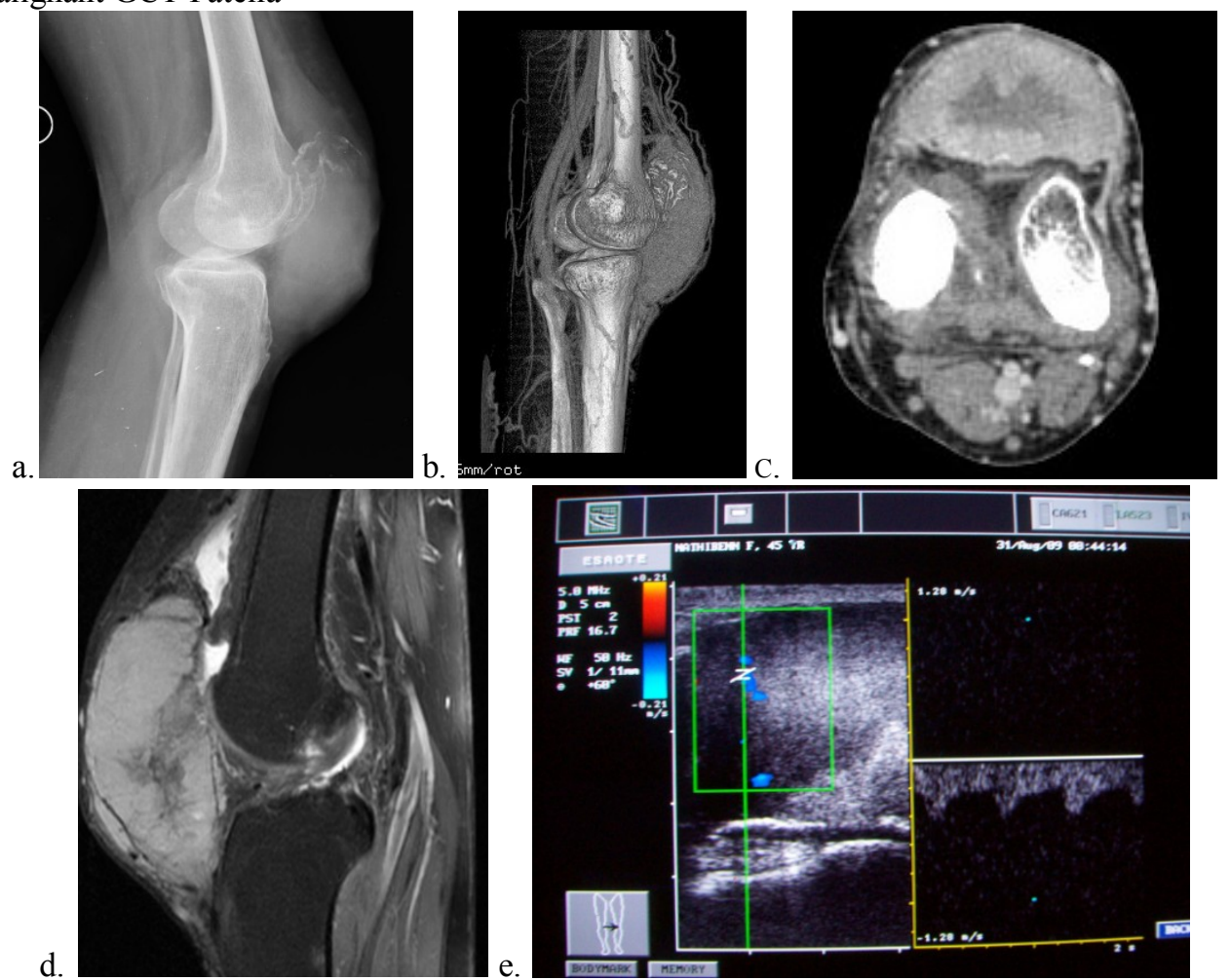

a. Expansile lytic lesion of patella with complete destruction of cortical outline and complete destruction of cortical outline with soft tissue replacing the bone b. Sagittal reconstruction CT image showing soft tissue mass replacing the patella $\mathrm{c}$. Post contrast axial $\mathrm{CT}$ image showing moderate peripheral enhancement of the lesion with central necrosis d. Post contrast Sagittal MRI image showing moderate enhancement of the lesion e.Arterial Doppler image showing arterial flow within it

Case 5 : Giant cell reparative granuloma:
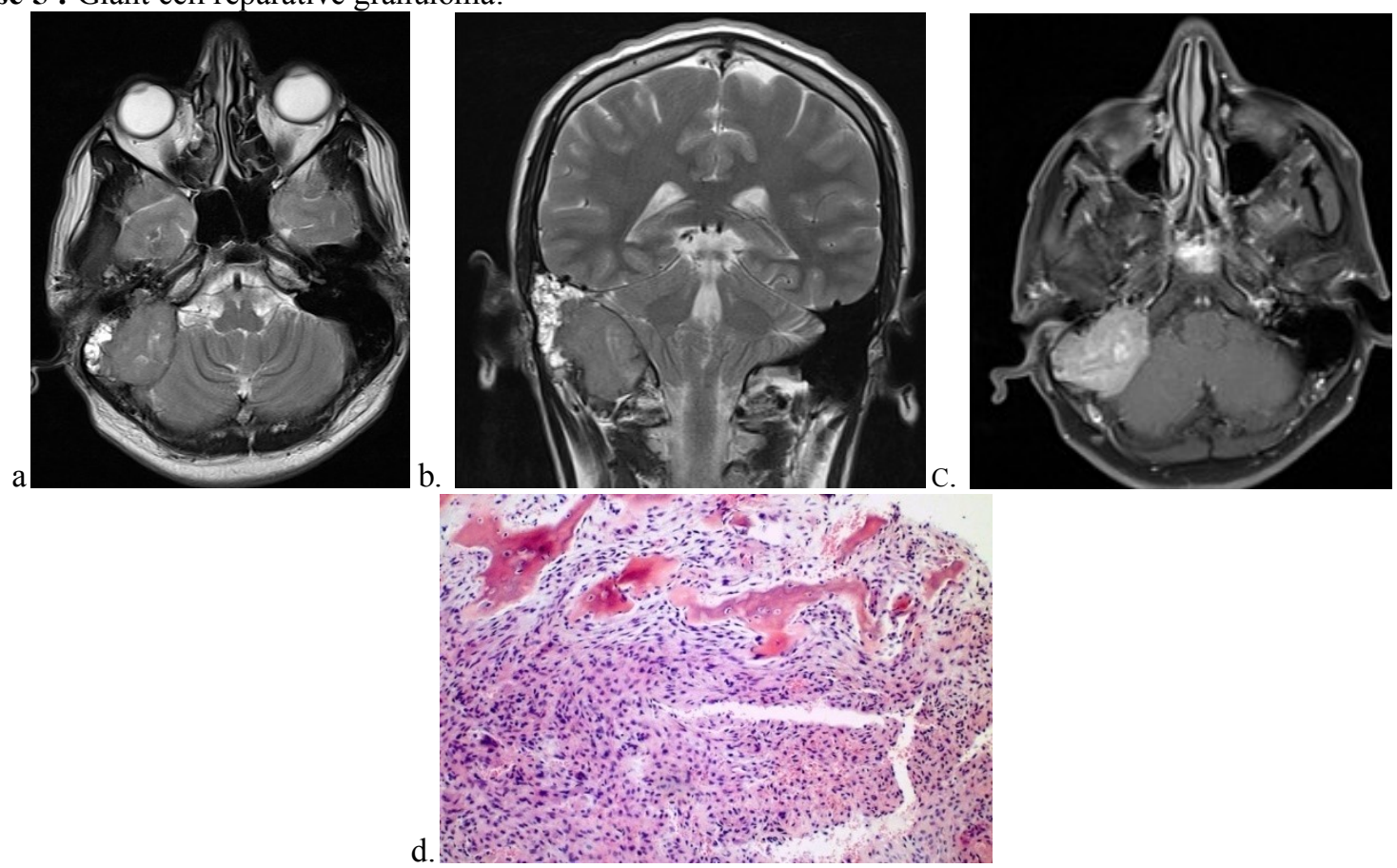
a,b: Axial and coronal T2WI showing a well defined mass lesion involving the right temporal bone;it appears isointense to the cortex on T2WI.c:Post contrast axial image showing intense enhancement of the lesion $\mathrm{d}$ :Uneven distribution of giant cells in a background of mononuclear cells

\section{Conclusion :}

GCT and GCRG of bone often have a characteristic radiographic appearance. A diagnosis of GCT is suggested by a non mineralized, lytic, eccentric meta epiphyseal lesion involving a long bone and extending to subarticular bone in a skeletally mature patient. GCRG has a similar radiographic appearance but most commonly affects the mandible, maxilla, hands, or feet. CT and MR imaging are useful for staging these lesions and particularly for defining their soft-tissue extent. These modalities also allow detection of cystic (secondary ABC) components, frequently with fluid levels, seen in some GCTs. However, there are both solid and cystic components in GCT, allowing distinction from primary $\mathrm{ABC}$, which contains only cystic regions. Biopsy must be directed at the solid regions of GCT, which harbor diagnostic tissue. Unlike in many musculoskeletal neoplasms, the solid components of GCT demonstrate low to intermediate signal intensity at T2-weighted MR imaging. This feature can be helpful in diagnosis, particularly in lesions in unusual locations, and in distinguishing GCT from other subarticular lesions (large solitary subchondral cyst, intraosseous ganglia, Brodie abscess). GCT is typically solitary, whereas multiple GCTs rarely occur and may be associated with Paget disease. Malignant GCT is unusual, accounting for $5 \%-10 \%$ of all GCTs. These lesions most commonly arise as secondary lesions following irradiation of benign GCT. Surgical resection is currently associated with a lower recurrence rate $(2 \%-25 \%)$ than has been historically seen $(40 \%-60 \%)$ as a result of extension of surgical margins with a variety of methods. The spectrum of radiologic features of GCT and GCRG of bone reflects their pathologic appearance. Recognition of these features usually allows prospective diagnosis, helps guide therapy, and facilitates early detection of recurrence, thereby improving clinical case management.

\section{Acknowledgements:}

Special thanks to Dr.Nandini Bahri - Professor and Head of dept of Radiology, M.P. Shah Medical college and G.G. Hospitals, Jamnagar under whose guidance this study was carried out. She was an unexhausting source of support without which it would not have been possible to bring this study out in its present form.

\section{References:}

[1]. Cooper A, Travers B. Surgical essays 3rd ed. London, England: Cox \& Son, 1818

[2]. Manaster BJ, Doyle AJ. Giant cell tumors of bone. Radiol Clin North Am 1993; 31:299-323. [Medline][Medline]

[3]. Unni KK. Dahlin's bone tumors: general aspects and data on 11,087 cases 5th ed. Philadelphia, Pa: Lippincott-Raven, 1996.

[4]. Larsson SE, Lorentzon R, Boquist L. Giant cell tumor of bone. J Bone Joint Surg [Am] 1975; 57:167-173. [Medline][Medline]

[5]. Resnick D, Kyriakos M, Greenway GD. Tumors and tumor-like lesions of bone: imaging and pathology of specific lesions Diagnosis of bone and joint disorders. 3rd ed.

[6]. Philadelphia, Pa: Saunders, 1995; 3628-3938.

[7]. Dorfman HD, Czerniak B. Giant-cell lesions. In: Dorfman HD, Czerniak B, eds. Bone tumors. St Louis, Mo: Mosby, 1998; 559606.

[8]. Mirra JM. Bone tumors: clinical, radiologic and pathologic correlations 2nd ed. Philadelphia, Pa: Lea \& Febiger, 1989.

[9]. Joyner CJ, Quinn JM, Triffit JT, Owen ME, Athanasou NA. Phenotypic characterisation of mononuclear and multinucleated cells of giant cell tumour of bone. Bone Miner

[10]. 1992; 16:37-48. [CrossRef][CrossRef] [Medline][Medline]

[11]. Frassica FJ, Sanjay BK, Unni KK, McLeod RA, Sim FH. Benign giant cell tumor. Orthopedics 1993; 16:11791183.[Medline][Medline]

[12]. Sung HW, Kuo WP, Chai YB, Liu CC, Li SM. Giant cell tumor of bone: analysis of two hundred and eightcases in Chinese patients. J Bone Joint Surg [Am]

[13]. 1982; 64:755-761. [Medline][Medline]

[14]. Reddy CRRM, Rao PS, Rajakumari K. Giant cell tumors of bone in south India. J Bone Joint Surg[Am] 1974; 56:617-619. [Medline][Medline]

[15]. Yang DZ. Clinicopathologic analysis of giant cell tumor of the bone: report of 35 cases. Zhonghua Zhong Liu ZaZhi 1985; 7:200202. [Chinese]. [Medline][Medline]

[16]. Moser RP, Kransdorf MJ, Gilkey FW, Manaster BJ. Giant cell tumor of the upper extremity. RadioGraphics 1990; 10:83-102. [Abstract] [Medline][Medline]

[17]. Hudson TM, Schiebler M, Springfield DS, Enneking WF, Hawkins IF, Spanier SS. Radiology of giant cell tumors of bone: computed tomography, arthro- tomography,

[18]. and scintigraphy. Skeletal Radiol 1984; 11:85-95. [CrossRef][CrossRef] [Medline][Medline]

[19]. McInerney DP, Middlemiss JH. Giant cell tumor of bone. Skeletal Radiol 1978; 2:195-204. [CrossRef][CrossRef]

[20]. GOLDENBERG RR,CAMPBELL CJ,BONFIGILIO M.GIANT CELL TUMOR OF BONE:AN ANALYSIS OF 218 CASES.J BONE JOINT SURG[AM]1970;52:619-664[Medline][Medline]

[21]. KRANSDORF MJ,MOSER RP,JR,VINH TN,AOKI J,CALLAGHAN JJ.PRIMARY TUMORS OF THE PATELLA:A REVIEW OF 42 CASES. [Medline][Medline] SKELETAL RADIOL 1989;18:365-371.[CrossRef][CrossRef]

[22]. Kransdorf MJ, Sweet DE, Buetow PC, Giudicci MAI, Moser RP. Giant cell tumor in skeletally immature PATIENTS.RADIOLOGY 1992;184:233-237[Abstract] [Medline][Medline] 
[23]. Campanacci M, Baldini N, Boriani S, Sudanese A. Giant cell tumor of bone. J Bone Joint Surg [Am] 1987; 69:106-114 [Medline][Medline]

[24]. Campanacci M, Giunti A, Olmi R. Giant cell tumors of bone: a study of 209 cases with long term followup in 130. Ital J Orthop Traumatol 1975; 1:249-277.

[25]. Carrasco CH, Murray JA. Giant cell tumors. Orthop Clin North Am 1989; 20:395-405. [Medline][Medline]

[26]. Dahlin DC, Cupps RE, Johnson EW, Jr. Giant cell tumor: a study of 195 cases. Cancer 1970; 25:1061-1070. [CrossRef][CrossRef] [Medline][Medline]

[27]. ECKARDT J.,GROGAN T. GIANT CELL TUMOR OF BONE.CLIN ORTHOP.1986; 204:45-58. [Medline][Medline] HUVOS AG, ed. Bone tumors: diagnosis, treatment, and prognosis Philadelphia, Pa: Saunders, 1991

[28]. Turcotte RE, Sim FH, Unni KK. Giant cell tumor of the sacrum. Clin Orthop 1993; 291:215-221. [Medline][Medline]

[29]. CAMPBELL C, Bonfiglio M. Aggressiveness and malignancy in giant cell tumors of bone. In: Price CHG, Ross FGM, eds. Bone: certain aspects of neoplasia. London, England: Colston Research Society, 1973; 55-65.

[30]. Abhaynkar SC, Johari AN, Baralay SB, Ramani PS. Giant cell tumors of vertebral column. Indian J Pathol Microbiol 1988; $31: 75-$ 79. [Medline][Medline]

[31]. DiLorenzo N, Nardi P, Ciapetta P, Fortuna A. Benign tumors and tumorlike conditions of the spine: radiological features, treatment and results. Surg Neurol 1986; 25:449-456. [CrossRef][CrossRef] [Medline][Medline]

[32]. Aoki J, Moser RP, Vinh TN. Giant cell tumors of the scapula: a review of 13 cases. Skeletal Radiol 1989;18:427-434. [CrossRef][CrossRef] [Medline][Medline]

[33]. Sherwani RK, Zaheer S, Sabir AB, Goel S. Giant cell tumor along with secondary aneurysmal bone cyst of scapula: a rare presentation. Int J Shoulder Surg 2008;2(3):59-61.

[34]. LEVINE E, DeSmet AA, Neff JR. Role of radiologic imaging in management planning of giant cell tumor of bone. Skeletal Radiol 1984; 12:79-89. [CrossRef][CrossRef] [Medline][Medline]

[35]. Murphey MD, Nomikos GC, Flemming DJ, Gannon FH, Temple HT, Kransdorf MJ. Imaging of giant cell tumor and giant cell reparative granuloma of bone: radiologic-pathologic correlation. RadioGraphics 2001;21(5):1283-1309

[36]. HERMAN SD, Mesgarzadeh M, Bonakdarpour A, Dalinka MK. The role of magnetic resonance imaging in giant cell tumor of bone. Skeletal Radiol 1987; 16:635-643. [CrossRef][CrossRef] [Medline][Medline]

[37]. Lee MJ, Sallomi DF, Munk PL, et al. Pictorial review: giant cell tumours of bone. Clin Radiol 1998; 53:481-489. [CrossRef][CrossRef] [Medline][Medline]

[38]. Murphey MD, Smith WS, Al-Assir I, Shekitka KM. MR imaging of giant cell tumor of bone (abstr). Radiology 1995; $197(\mathrm{P}): 195$. [Abstract] [Medline][Medline]

[39]. Aoki J, Tanikawa H, Ishii K, et al. MR findings indicative of hemosiderin in giant cell tumor of bone: frequency, cause, and diagnostic significance. AJR Am J Roentgenol 1996; 166:145-148. [CrossRef][CrossRef] [Medline][Medline]

[40]. AOKI J, Moriya K, Yamashita K, et al. Giant cell tumors of bone containing large amounts of hemosiderin: MR-pathologic correlation. J Comput Assist Tomogr 1991; 15:1024-1027. [CrossRef][CrossRef] [Medline][Medline]

[41]. MARTINEZ V, Sissons HA. Aneurysmal bone cyst: a review of 123 cases including primary lesions and those secondary to other bone pathology. Cancer 1988; 61:2291-2304. [CrossRef][CrossRef] [Medline][Medline]

[42]. Abdelwahab IF, Kenan S, Hermann G, Klein MJ, Lewis MM. Case report 845: fluid-filling giant cell tumor with an aneurysmal bone cyst component. Skeletal Radiol 1994; 23:317-319. [CrossRef][CrossRef] [Medline][Medline]

[43]. Kransdorf MJ, Sweet DE. Aneurysmal bone cyst: concept, controversies, patient presentation, and imaging. AJR Am J Roentgenol 1995; 164:573-580. [CrossRef][CrossRef] [Medline][Medline]

[44]. Casadei R, Ruggieri P, Moscato M, Ferraro A, Picci P. Aneurysmal bone cyst and giant cell tumor of the foot. Foot Ankle Int 1996; 17:487-495. [CrossRef][CrossRef] [Medline][Medline]

[45]. Vergel De Dios AM, Bond JR, Shrives TC, McLeod RA, Unni KK. Aneurysmal bone cyst: a clinicopathologic study of 238 cases. Cancer 1992; 69:2921-2931. [CrossRef][CrossRef] [Medline][Medline]

[46]. Kaplan PA, Murphey MD, Greenway G, Resnik D, Sartoris DJ, Harms S. Fluid-fluid levels in giant cell tumors of bone: report of two cases. J Comput Tomogr 1987; 11:151-155. [CrossRef][CrossRef] [Medline][Medline]

[47]. Tsai JC, Dalinka MK, Fallon MD, Zlatkin MB, Kressel HY. Fluid-fluid level: a nonspecific finding in tumors of bone and soft tissue. Radiology 1990; 175:779-782. [Abstract] [Medline][Medline]

[48]. Sakkers RJB, Van Der Heul RO, Kroon HM, Taminiau AHM, Hogendoorn PCW. Late malignant transformation of a benign giant cell tumor of bone: a case report. J Bone Joint Surg Am 1997; 79:259-262. [Medline][Medline]

[49]. Marui T, Yamamoto T, Yushihara H, Kurosaka M, Mizonu K, Akamatsu T. De novo malignant transformation of giant cell tumor of bone. Skeletal Radiol 2001; 30:104-108. [CrossRef][CrossRef] [Medline][Medline]

[50]. Davis A, Bell RS, Allan DG, Langer F, Czitrom AA, Gross AE. Fresh osteochondral transplants in the treatment of advanced giant cell tumors. Orthopade 1993; 22:146-151. [German]. [Medline][Medline]

[51]. O’Donnell RJ, Springfield DS, Motwani HK, Ready JE, Gebhardt MC, Mankin HJ. Recurrence of giant cell tumors of the long bones after curettage and packing with cement. J Bone Joint Surg Am 1994; 76:1827-1833. [Medline][Medline]

[52]. Blackley HR, Wunder JS, Davis AM, White LM, Kandel R, Bell RS. Treatment of giant-cell tumors of long bones with curettage and bone-grafting. J Bone Joint Surg Am 1999; 81:811-820. [Medline][Medline]

[53]. Malawer MM, Bickels J, Meller I, Buch RG, Henshaw RM, Kollender Y. Cryosurgery in the treatment of giant cell tumor: a longterm follow-up study. Clin Orthop 1999; 359:176-188. [CrossRef][CrossRef] [Medline][Medline]

[54]. Capanna R, Fabbri N, Bettelli G. Curettage of giant cell tumors of bone: the effect of surgical technique and adjuvants on local recurrence rate. Chir Organi Mov 1990; 75(suppl 1):206. [Medline][Medline]

[55]. Komiya S, Inoue A. Cementation in the treatment of giant cell tumor of bone. Arch Orthop Trauma Surg 1993; 112:51-55. [CrossRef][CrossRef] [Medline] [Medline]

[56]. Marcove RC, Miller TR, Cahan WC. The treatment of primary and metastatic bone tumors by repetitive freezing. Bull N Y Acad Med 1968; 44:532-544. [Medline][Medline]

[57]. Rock M. Adjuvant management of benign tumors: basic concepts of phenol and cement use. Chir Organi Mov 1990; 75(suppl 1):195-197. [Medline][Medline]

[58]. Lee FY, Montgomery M, Hazan EJ, Keel SB, Mankin HJ, Kattapuram SV. Recurrent giant cell tumor presenting a soft tissue mass: a report of four cases. J Bone Joint Surg Am 1999; 81:703-707. [Medline][Medline]

[59]. Remedios D, Saifuddin A, Pringle J. Radiological and clinical recurrence of giant cell tumour of bone after the use of cement. J Bone Joint Surg Br 1997; 79:26-30. [CrossRef][CrossRef] [Medline][Medline]

[60]. Richardson ML, Lough LR, Shuman WP, Lazerte GD, Conrad EU. MR appearance of skeletal neoplasms following cryotherapy. Skeletal Radiol 1994; 23:121-125. [CrossRef][CrossRef] [Medline][Medline] 
[61]. Kattapuram SV, Phillips WC, Mankin HJ. Giant cell tumor of bone: radiographic changes following local excision and allograft replacement. Radiology 1986; 161:493-498. [Abstract] [Medline][Medline]

[62]. Pettersson H, Rydholm A, Persson B. Early radiologic detection of local recurrence after curettage and acrylic cementation of giant cell tumors. Eur J Radiol 1986; 6:1-4. [Medline][Medline]

[63]. Waldman BJ, Zerhouni EA, Frassica FJ. Recurrence of giant cell tumor of bone: the role of MRI in diagnosis. Orthopedics 1997; 20:67-69. [Medline][Medline]

[64]. Bibas-Bonet H, Fauze RA, Lavado MG, et al. Garcin syndrome resulting from a giant cell tumor of the skull base in a child. Pediatr Neurol 2003;28:392-95,

[65]. Yamaguchi T, Dorfman HD. Giant cell reparative granuloma: a comparativeclinicopathologic study of lesions in gnathic and extragnathic sites. Int J SurgPathol 2001;9:189-200

[66]. Boedeker CC, Kayser G, Ridder GJ, et al. Giant-cell reparative granuloma of thetemporal bone. Ear Nose Throat J 2003;82:926-37

[67]. Sharma RR, Mahapatra AK, Pawar SJ, et al. Craniospinal giant cell tumors.J Clin Neurosci 2002;9:41-50

[68]. Yamaguchi T, Dorfman HD. Giant cell reparative granuloma: a comparative clinicopathologic study of lesions in gnathic and extragnathic sites. Int J Surg Pathol 2001;9:189-200 